\title{
Correction to: Gene Editing Rescues in Vitro T Cell Development of RAG2-Deficient Induced Pluripotent Stem Cells in an Artificial Thymic Organoid System
}

\author{
Cameron L. Gardner ${ }^{1,2}$ - Mara Pavel-Dinu ${ }^{3} \cdot$ Kerry Dobbs $^{1} \cdot$ Marita Bosticardo $^{1}$ • Paul K. Reardon ${ }^{2}$ - Justin Lack ${ }^{4,5}$. \\ Suk See DeRavin ${ }^{1} \cdot$ Kent Le $^{1} \cdot$ Ezekiel Bello $^{1}$ - Francesca Pala ${ }^{1}$. Ottavia M. Delmonte ${ }^{1} \cdot$ Harry Malech ${ }^{1}$. \\ Amelie Montel-Hagen ${ }^{6} \cdot$ Gay Crooks $^{6}$. Oreste Acuto ${ }^{2} \cdot$ Matthew H. Porteus ${ }^{3} \cdot$ Luigi D. Notarangelo $^{1}$ (I)
}

Published online: 5 April 2021

(C) Springer Science+Business Media, LLC, part of Springer Nature 2021

\section{Correction to: Journal of Clinical Immunology} https://doi.org/10.1007/s10875-021-00989-6

The original article contained a typo in the family name of one of the authors. In particular, the correct author's name is: Amelie Montel-Hagen. It is also corrected above.

Publisher's Note Springer Nature remains neutral with regard to jurisdictional claims in published maps and institutional affiliations.

The online version of the original article can be found at https://doi.org/ 10.1007/s10875-021-00989-6

\footnotetext{
Oreste Acuto

oreste.acuto@path.ox.ac.uk

$\triangle$ Matthew H. Porteus

mporteus@stanford.edu

Luigi D. Notarangelo

luigi.notarangelo2@nih.gov

1 Immune Deficiency Genetics Section, Laboratory of Clinical Immunology and Microbiology, DIR, NIAID, NIH, 10 Center Drive, Bldg. 10 CRC, Room 5-3950, Bethesda, MD 20892-1456, USA

2 Sir William Dunn School of Pathology, University of Oxford, Oxford OX14RE, UK

3 Division of Stem Cell Transplantation and Regenerative Medicine, Department of Pediatrics, Stanford School of Medicine, Stanford University, Stanford, CA, USA

4 NIAID Collaborative Bioinformatics Resource, NIAID, NIH, Bethesda, MD, USA

5 Advanced Biomedical Computational Science (ABCS), Frederick National Laboratory for Cancer Research, Frederick, MD, USA

6 Department of Pathology and Laboratory Medicine, David Geffen School of Medicine, University of California, Los Angeles, Los Angeles, CA, USA
} 